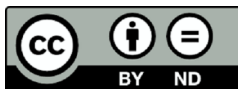

Acta Poloniae Historica

112,2015

PL ISSN 0001-6892

\title{
Adam Krawiec
}

Institute of History, Adam Mickiewicz University, Poznań

\section{THE CONCEPT OF SPACE IN THE CHRONICLE OF GALLUS ANONYMUS, THE MENTAL GEOGRAPHY OF ITS AUTHOR, AND THEIR SIGNIFICANCE FOR THE CONTROVERSY ON HIS PLACE OF ORIGIN}

\begin{abstract}
The paper deals with the question of geographical imaginations of so-called Gallus Anonymus, as prevalent in his chronicle. The author sought to reconstruct the chronicler's mental map of Europe, especially of Sclavonia (Slavonic countries), or, precisely, the concept of space (Raumkonzept) of his work, and the possible sources of his imaginations and knowledge. The author takes under consideration the possibilities of using the geographical data from the Chronicle in solving the controversy on Gallus's place of origin. The conclusion is that, contrary to often-held opinions, the data itself does not allow us to indicate any specific place or region of Gallus's birth and/or education.
\end{abstract}

Keywords: Gallus Anonymus, geographical imaginations, mental maps, Polish medieval historiography, Slavonic countries

The geographical issues stemming from the chronicle by the so-called Gallus Anonymus has long aroused interest among research scholars, understandably enough. Apart from the Dagome iudex document, Gallus's Chronica offers the earliest description of the territory of Poland and one of the oldest detailed descriptions of Slavdom (Slavonic lands). This positions the chronicle at the outset of Polish historiography as well as geographic literature. Yet, the interest expressed by scholars has been rather specific. There have been not many studies examining the topic closer, as an autonomous research issue. In fact, Teodor Tyc has been the only one to have thoroughly analysed Gallus's geographical knowledge and imaginations, focusing on the problem as an autonomous research subject-matter. ${ }^{1}$ Franciszek

\footnotetext{
${ }^{1}$ Teodor Tyc, Z dziejów kultury w średniowiecznej Polsce (Poznań, 1924), 83 ff.
} 
Bujak's and Brygida Kürbis's brief discussions of Gallus's ideas about Poland and Slavdom ${ }^{2}$ and Dariusz Rott's genological considerations related to the description of Poland and Slavdom that opens the chronicle and is found elsewhere in it, as an example of the genre of chorography, ${ }^{3}$ complement the picture. The topic of imaginative geography in Gallus's chronicle has been briefly analysed by the undersigned. ${ }^{4}$ Since the Maksymilian Gumplowicz treatise, ${ }^{5}$ the spatial elements in Gallus's chronicle have been examined primarily in the context of considerations on the author's place of origin. Most of these analyses have regretfully been rather superficial, neglecting the context of European imaginative geography of the late eleventh and early twelve century. Interestingly, the geographical data provided in the chronicle - rather modest as they are - have been used by authors in support of their extremely diverse ideas.

It would be legitimate, I presume, to define shortly some of the notions used in the present considerations. It is thought-provoking that the dynamic evolution taking place in the recent decades in research of the spatial aspect of the functioning of individuals and communities, in our time as well as in the past, ${ }^{6}$ has not led yet to the elaboration of a general conceptual framework related to the phenomena under research, one that would be universally accepted by scholars. I have earlier on attempted to give a clearer order to some of the terms related to space as a cultural context ${ }^{7}$ - which means not the really and objectively existing space surrounding humans but

2 Franciszek Bujak, 'Geografja kronikarzy polskich', in idem, Studja geograficznohistoryczne (Kraków, 1925), 79; Brygida Kürbis, 'Kształtowanie się pojęć geograficznych o Słowiańszczyźnie w polskich kronikach przeddługoszowych', Slavia Antiqua, iv (1953), 273-5.

${ }_{3}$ Dariusz Rott, Staropolskie chorografie. Początki, rozwój, przemiany gatunku (Katowice, 1995), 66-85.

${ }^{4}$ Adam Krawiec, Ciekawość świata $w$ średniowiecznej Polsce. Studium $z$ dziejów geografii kreacyjnej (Poznań, 2010), 252-5, 329-32, 358-9.

${ }_{5}$ Maksymilian Gumplowicz, Bischof Balduin Gallus von Kruszwica, Polens erster lateinischer Chronist (Wien, 1895), $36 \mathrm{ff}$.

${ }^{6}$ For a general discussion of this research and its influence on modern medieval studies, mainly American and French, cf. Meredith Cohen, Fanny Madeline, and Dominique Iogna-Prat, 'Introduction', in Meredith Cohen and Fanny Madeline (eds.), Space in the Medieval West. Places, Territories, and Imagined Geographies (Farnham, 2014), 1-17.

${ }^{7}$ Krawiec, Ciekawość świata, 48-57. 
rather, the space as it is perceived by these people and (re)constructed in their minds. The term 'geographical imaginations' refers to the way in which people represent a given area to/for themselves. ${ }^{8}$ Aggregated geographical imaginations of individual people compose their 'mental geographies'. ${ }^{9}$ The way in which the space is ordered by man, based on arranging the places and territories known to them, and attributing them specific meanings and narratives, would be described as a 'mental map'. ${ }^{10}$ 'Imaginative geography' would be a broader term: ${ }^{11}$ in my approach, imaginative geography forms as if an intersection, or

${ }^{8}$ The notion 'geographical imaginations' has been variously defined by Englishlanguage authors; recently, as "encounters with the geographical through subjectively experienced and embodied spatial practices, using images and texts to map out these 'imagined geographies' [i.e., the geographical traditions]", as in Keith D. Lilley, 'Introduction: mapping medieval geographies', in idem (ed.), Mapping Medieval Geographies. Geographical Encounters in the Latin West and Beyond, 300-1600 (Cambridge, 2013), 2; also, cf. ibidem, 12 ff.

${ }^{9}$ The term 'mental geography' is broadly used in psychology and sociology; it is also known to historical sciences (though less popular there), as for instance (with respect to the Middle Ages): Robert Bartlett, 'Heartland and Border: The Mental and Physical Geography of Medieval Europe', in Huw Pryce and John Watts (eds.), Power and Identity in the Middle Ages: Essays in Memory of Rees Davies (Oxford, 2011), 45 ff; Daniel L. Smail, Imaginary Cartographies: Possession and Identity in Late Medieval Marseille (Ithaca, 1999), 1-41. The notion is understood somewhat differently by the different authors, transgressing, at times, the limits of geography (in the strict sense of the term) and referring to an overall vision of the world - as e.g. in Robert Bartlett, The Natural and the Supernatural in the Middle Ages (Cambridge, 2008), 16-17.

${ }^{10}$ The notion of 'mental map' has been long used in psychology; historical sciences, including medieval studies, have taken it over. For a general discussion on the meaning of this term cf., in particular, Yi-Fu Tuan, 'Images and Mental Maps', Annals of the Association of American Geographers, lxv (1975), 211; Jouko Keski-Säntti, Ulla Lehtonen, Pauli Sivonen, and Ville Vuolanto, 'The Drum as Map: Western Knowledge Systems and Northern Indigenous Map Making', Imago Mundi, lv, 1 (2003), 124, n. 1. The latter study differentiates between 'unmanifested mental maps' - images only existing in the minds of people; 'manifested mental maps' - the visual representations of these images: drawings, diagrams, and the like; and, 'maps' (in the strict sense).

${ }^{11}$ The notion of 'imaginative geography' was introduced by Edward W. Said, see idem, Orientalism (New York, 1978), and made widespread by representatives of the so-called humanistic geography in the 1990s, especially, Derek Gregory, David Harvey, and Edward Soja. My use of this term is slightly diverse. Let me remark at this point that none of the critical remarks aimed at the concept discussed in Said's fundamental work, greatly legitimate as they have been, referred to this particular notion. 
common area, of the mental geographies of a given collectivity. It is definable as a set of geographical imaginations being considered true by at least a majority of members of a collectivity and confirmed by the authorities they approve of, and one that reflects (unconsciously, in most cases) the collectivity's prevalent system of values and power relations. There is a sort of feedback occurring between imaginative geography and mental geographies. On the one hand, imaginative geography, functioning within a society and enjoying authority among its members, forms - along with experience-based empirical knowledge - one of the two constituents for creation by the people of their mental geographies. On the other hand, it is mental geographies that imaginative geography prevalent across the community is constructed upon. In relation to the text or map, the concept of space (Raumkonzept $)^{12}$ corresponds with the function and significance of mental maps with respect to members of the collectivity. The concept of space is, namely, a meta-structure that organises the image of space contained in the text - or, putting it in simpler terms, the way space is presented in a given text of culture, encompassing the geographical data as well as the way they have been selected, characterised and evaluated, and their reciprocal relations. The concept of textual space cannot be equated to the mental map of the text's author since the former is informed by a number of external factors such as the work's practical purpose, the addressees' horizon of expectations, ${ }^{13}$ or literary convention employed. This causes a series of problems for historians, since the texts written by a given author provide, in practice, the only opportunity to penetrate into his mental geography. Therefore, the

12 The 'concept of space' is an idea extensively present in science; in most cases, it has been used with respect to the method of ordering or structuring the real physical space. In the meaning herein followed, it was introduced by Bernhard Jahn, Raumkonzepte in der frühen Neuzeit. Zur Konstruktion von Wirklichkeit in Pilgerberichten, Amerikareisebeschreibungen und Prosaerzählungen (Frankfurt am Main, 1993), esp. 18.

${ }^{13}$ The notion of 'horizon of expectations' (Erwartungshorizont) comes from literary research, where it was originally introduced by Hans R. Jauß, Literaturgeschichte als Provokation der Literaturwissenschaft (Konstanz, 1967). It denotes a complex of expectations related to a literary text (and any text of culture) by its potential addressees at the time it is written. In most cases, the horizon of expectations is a construct created by scholars based on the related period's source information and general knowledge; cf. Uwe Spörl, 'Erwartungshorizont', in idem, Basislexikon Literaturwissenschaft (Paderborn, 2004), 130-2. 


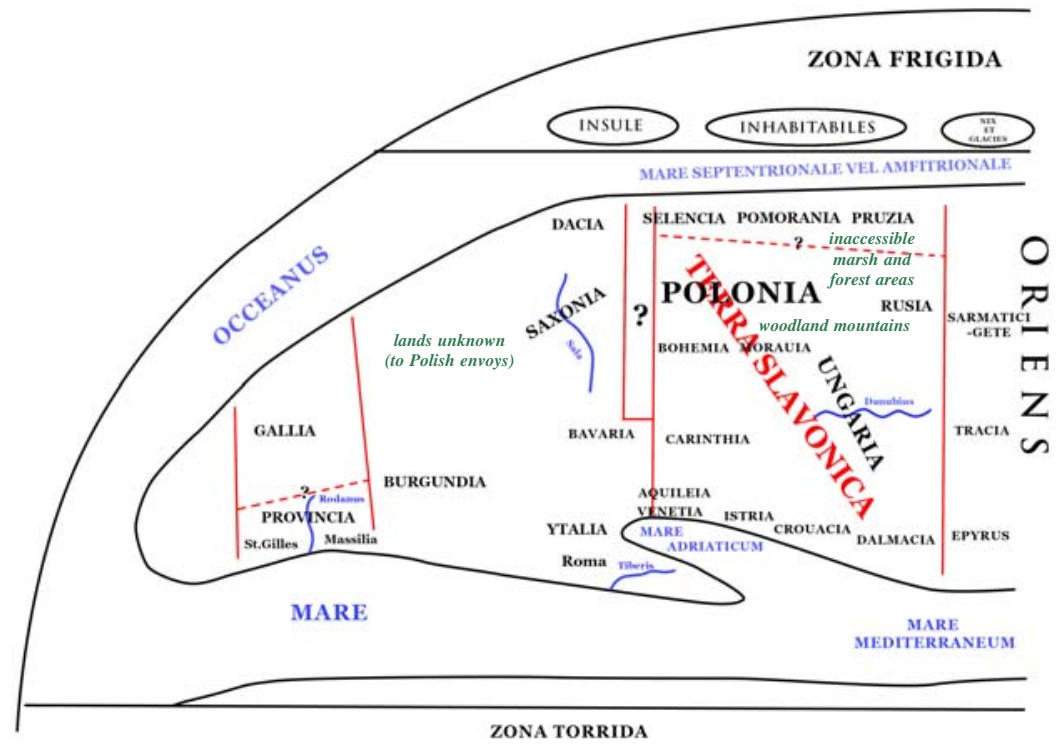

Fig. 1

possibility to reconstruct a mental map and, thereby, the actual geographical knowledge of the people living in the past is always limited.

In my research into the geographical imaginations identifiable in Gallus Anonymus's chronicle, I have attempted at reconstructing the concept of the work's textual space in a graphic form (Fig. 1). The map I have compiled covers no geographical objects from the area of Poland and Hungary: if present, they would make the map illegible and, more importantly, most of such localities cannot be plotted, if ever unambiguously identified, based on the text itself. Gallus would not use specific local names in a number of cases; thus, we would basically project our knowledge of the geography of Polish lands and central Europe on the data recognised in the chronicle rather than reconstruct the concepts, or imaginations, of Gallus (possibly, to the extent he intended to share them with the readers). In any case, this chronicler offers quite sparse information which could help identify him or better recognise his geographical horizon. ${ }^{14}$ Symptomatically,

${ }^{14}$ What I mean, for the present purpose, by 'geographic horizon' is the scope of the territory which was known to the chronicler in more detail from personal inspection. 
it is impossible to point in the chronicle to any detailed information, related to the territory of Poland, which would enable to identify his whereabouts. T. Tyc was undoubtedly right in stating that Gallus "did not take much delight in topographical details". ${ }^{15}$ Against this general background, stand out the short but apt depictions of the natural landscapes of Prussia and the Silesian-Moravian borderland (II, 42, p. 112; II, 26, p. 93). ${ }^{16}$ However, in neither case can it be said whether we owe these descriptions to the chronicler's sense of observation, as a participant of the events, or they came from his informants.

It should be emphasised that the reconstruction proposed in this study is not a 'map of Gallus Anonymus's modelled into a vision of the type popular among nineteenth-century historians of cartography: Gallus probably never physically made a map; for certain, no map ever accompanied the text of his chronicle. I have already mentioned the necessity of differentiating between the concept of textual space, as reconstructed based on the chronicle, and the mental geography of its author. The probability that external factors may influence the content inherent in the text is particularly high with an author in (what we may think was) the Gallus's situation as an outsider who was forced to weave between factions and vested interests. One should refrain from ultimately concluding whether, for instance, the absence or poor presence of an area in the chronicle, and the expression of an emotional attitude toward it or a negative evaluation of an ethnic group, attests to the author's actual knowledge or attitude, whatever it might have been. ${ }^{17}$ Making a statement whereby the pointing by Gallus to some defined element in the cultural landscape (such as the uncompleted church in Bazoarium ${ }^{18}$ ) testifies that this author came - or, otherwise, would certainly not have come - from a specified

15 Tyc, Z dziejów kultury, 79.

${ }^{16}$ Cf. Bujak, 'Geografja', 79. For the image of Polish lands in Gallus, cf. Tyc, Z dziejów kultury, 102 ff.; Krawiec, Ciekawość świata, 254-5.

${ }^{17}$ For instance, "the chronicler's critical attitude towards Germans and Bohemians seems to preclude his possible nationality of either": Marian Plezia, 'Wstęp', in Anonim tzw. Gall, Kronika polska, trans. Roman Grodecki, ed. Marian Plezia (Wrocław, 1996), VII. (Putting aside the fact that 'German nationality' would have hardly been the case in twelfth-century realities.). Cf. Tyc's apt remarks in $Z$ dziejów kultury, 89-90.

${ }^{18}$ E.g., Wojciech Kętrzyński, 'Niektóre uwagi o autorze i tekście najdawniejszej kroniki polskiej', Roczniki Akademii Umiejętności. Wydziat Historyczny, liii (1909), 61; Marian Plezia, Kronika Galla na tle historiografii XII wieku (Kraków, 1947), 161. 
area, would exceed the limits of a legitimate scholarly conjecture. The difference between the concept of the chronicle's space and the mental geography of its author becomes even more explicit when one accepts the hypothesis whereby Gallus was identical with the 'Monk of the Lido' - the author of The Translation of Saint Nicholas.

In a nutshell, the imaginative geography of the educated elites in the Latin cultural circle of the eleventh/twelfth century - Gallus having been one of the circle - was based on a concept of a spherical Earth situated in the centre of the Universe. The terrestrial surface was divided into five latitudinal zones (zonae) delineated depending on the incidence angle of sunrays: a torrid zone around the equator, two temperate zones, and two frigid zones around the poles. ${ }^{19}$ The conviction prevailed that 'regular' people could not live in the (sub)arctic zones, the only inhabitants possibly being representatives of the monstrous races. The temperate zone would moreover be divided into seven subzones, so-called climates. ${ }^{20}$ The northern temperate zone was home to the known inhabited world - nostra habitabilis, the oecumene, itself divided into Asia, Europe, and Africa. An essential element of the image of the world was the unequal evaluation of the cardinal directions, or quarters of the terrestrial sphere. An extensive system of appraisals and their related significances attributed to the quarters/directions functioned: the East was evaluated in the most positive terms whereas the North aroused negative associations such as darkness, evil, and sin.

Maps of the world were visual representations of these ideas and imaginations. There were two major types of map in Gallus's time: (i) oecumenical maps, picturing the inhabited part of the world,

${ }^{19}$ Of the texts discussing the division of the heavenly and terrestrial spheres into five zones, let us mention the following: Isidori Hispalensis episcopi Etymologiarum sive Originum libri XX, ed. Wallace M. Lindsay (Oxford, 1911), III, 44; for a broader description, see Martianus Capella, 'De nuptiis Philologiae et Mercurii' [hereinafter: Martianus Capella], ed. James Willis (Leipzig, 1983), VI, 602-4, p. 211. Both works were well-known in Gallus's time.

${ }^{20}$ The climates were described in both of the mentioned texts: Isidori Hispalensis, III, 42; Martianus Capella, VIII, 876-7, pp. 331-2; cf. Stefan Schröder, 'Zur Hybridisierung mittelalterlicher Karten. Arabische, syrische und lateinische Illustrationen der sieben Klimazonen im Vergleich', in Michael Borgolte et al. (eds.), Integration und Desintegration der Kulturen im europäischen Mittelalter (Berlin, 2011), $474 \mathrm{ff}$. 
usually in a circular or (less frequently) oval form and east-oriented;21 (ii) hemispheric maps, showing the whole eastern hemisphere, usually north-oriented. ${ }^{22}$ As far as the graphic form is concerned, my reconstruction is based on the hemispherical map, also called 'Macrobian' as it usually accompanied manuscript editions of Macrobius's Commentarii in Somnium Scipionis. This particular type was widespread, and several dozen copies dated between the ninth and the twelfth century have come down to us. Importantly, they were known in the area of Gaul, Italy, and Germany. It is possible that an encounter with such a map informed the chronicler's approach and way of thinking about the geographical space and his use of a model according to which the space was arranged in his description of the Slavonic lands. Currently, though, no specific copy is identifiable due to the differences between the names used in the maps we know of and in Gallus's chronicle. ${ }^{23}$

In the time of Gallus, the system of ideas (imaginations) in question was taught at schools, mainly on the basis of texts of ancient origin or based on ancient sources. In effect, descriptions of the medieval authors' contemporary reality usually used geographical terms of ancient provenance, oftentimes applied to novel political or ethnic entities having nothing to do with what the ancient authors might have

${ }^{21}$ Maps showing mainly the oecumene but also having an imaginary 'rest of the world' plotted in the form of an additional narrow strip on the edge (so-called Beatus's maps) also appeared, rather sporadically, in the Early Middle Ages; however, this type of representation obsolesced in Gallus's time.

22 The medieval cartography has an extensive literature. For a general specificity and classification of the maps, see, in particular, David Woodward, 'Medieval Mappae Mundi', in John B. Harley and David Woodward (eds.), The History of Cartography, i: Cartography in Prehistoric, Ancient, and Medieval Europe and the Mediterranean (Chicago, 1987), 286-350; Evelyn Edson, Mapping Time and Space: How Medieval Mapmakers Viewed Their World (London, 1997), 1-18; Krawiec, Ciekawość świata, 62-82.

${ }^{23}$ In any case, this would not be a map of Slavdom or Poland as figured out (e.g.) by Kürbis, 'Kształtowanie się pojęć', 256 ("It would be outright unbelievable that some school-formatted map was not a source for Gallus to precisely situate Poland"), since no satisfactorily exact maps of the territory were available at the time; the first such maps, as known to us, were made as late as in the fifteenth century. Cf. Karol Buczek, Dzieje kartografii polskiej od XV do XVIII wieku. Zarys analityczno-syntetyczny (Wrocław, 1963), 15 ff. For known Macrobian maps from the earlier Middle Ages see Alfred Hiatt, 'The Map of Macrobius before 1100', Imago Mundi, lix, 2 (2007), 149-76. 
had in mind. Nonetheless, the geographical tradition of the time ${ }^{24}$ was focused on the ancient Mediterranean. Authors such as Gallus, who would intend to possibly minutely describe the territory of the central part of the continent - had therefore no model to refer to and build, instead, the image of the area described based on the empirical knowledge. On the other hand, the ancient authorities were so powerful that medieval authors tended to combine these empirical data with elements of paradigmatic knowledge derived from the ancient heritage - an approach that lasted throughout the Middle Ages and continued into the early modern period. Such association of paradigmatic and empirical knowledge can also be found in Gallus's chronicle. ${ }^{25}$

In his description of Slavdom, Gallus uses the pattern based on the territory's division into three latitudinal zones (Fig. 2). ${ }^{26}$ This concept should be seen as relating to the period's concepts of division of the Earth's surface into five zones, with the moderate zone subdivided into seven climates. Such conceptualisation of the geographical space implies, among other things, the belief that an uninhabited area stretches north of Poland and its adjacent countries - a snowand ice-covered land; this clearly refers to the concept of the zonae frigidae. The description of the terrae Sclavonicae commenced from the East also echoes the geographical tradition as it refers to the thenwidespread symbolism of the directions of the world. ${ }^{27}$ Notably, such $2 \mathrm{ff}$.

${ }^{24}$ For more on the notion of 'geographical tradition', cf. Lilley, 'Introduction',

25 The role of book-based geographical knowledge in Gallus's construction of an image of Europe (specifically, the Mediterranean) has recently been emphasised by Daniel Bagi, Królowie węgierscy w Kronice Galla Anonima (Kraków, 2008), 181. A different approach was taken with respect to the Gallus description by the earlier scholars; Brygida Kürbis, e.g., emphasised that "the life itself must have suggested" the chronicler's geographical data, whereas his work fits within the trend of the period's geography which "took into account the real acquaintance with Eastern Europe, without habilitating it in unworldly details"; eadem, "Kształtowanie się pojęć', 274.

${ }^{26}$ Teodor Tyc was probably the first to have noticed this; idem, $Z$ dziejów kultury, 85.

${ }^{27}$ Let us remind that in the somewhat earlier and less precise description by Adam of Bremen, the 'longitude' (latitudinal extent) of Slavdom was described looking from the West - 'from our point' (being the chronicler's viewpoint) toward the East: "Longitudo autem illa videtur, quae initium habet ab nostra Hammaburgensi parrochia et porrigitur in orientem, infinitis aucta spatiis, usque in Beguariam, Ungriam et Graeciam"; cf. Magistri Adam Bremensis Gesta Hammaburgensis ecclesiae 


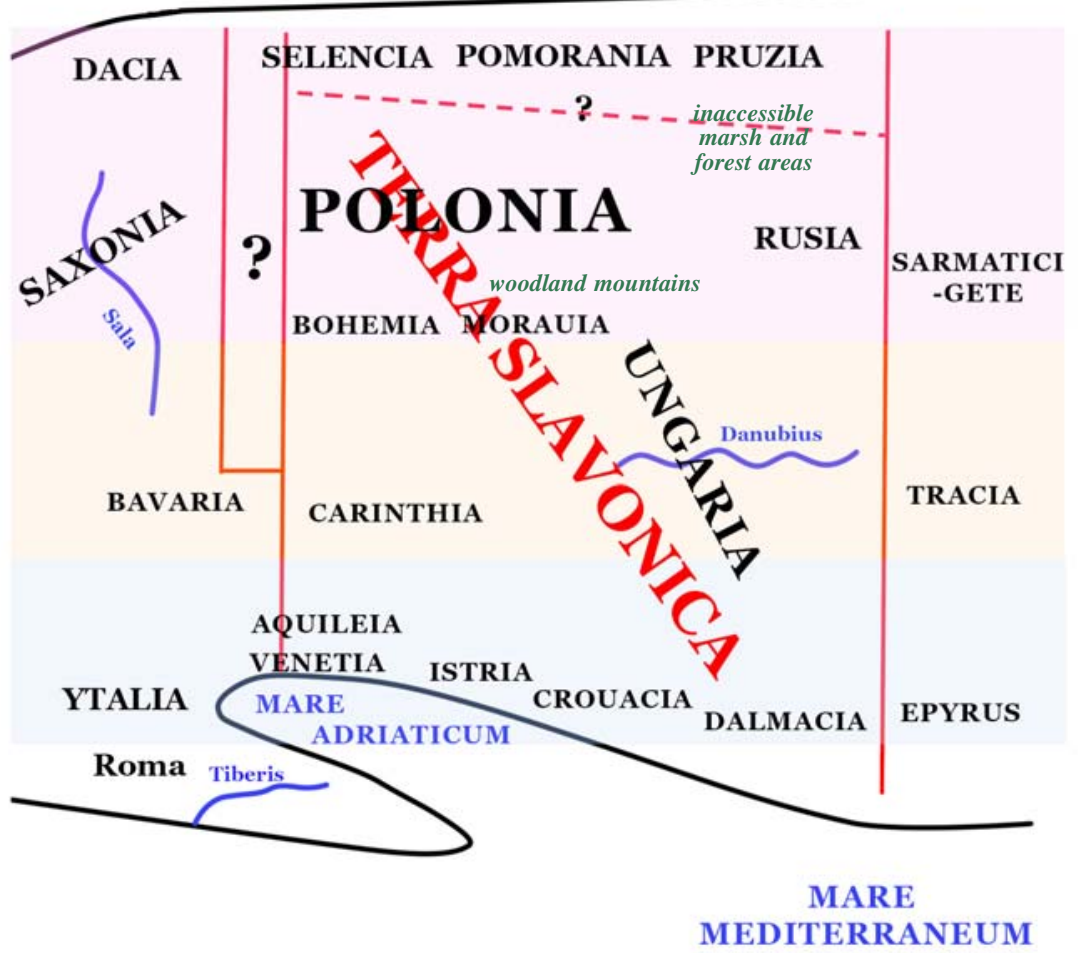

Fig. 2

structure of description (the division into latitudinal zones) is unique, given the contemporary literary output, without a counterpart in any other contemporary description of Slavonic lands, or any other part of Europe.

A certain portion of the nomenclature applied by Gallus is of the learned, ancient sort. Significantly, his description of the eastern range of the terrae Sclavonicae uses names of ancient origin: Epirus, Thrace, Sarmatians, Gethians (even if the first two were still in use as categories referring to his contemporary spatial relations). This might have partly been owed to insufficient knowledge, masked by reference to

pontificum, ed. Georg Waitz (MGH, SRG, 2, Hannover and Leipzig, 1917), II, 21, p. 76. On the other hand, Adam begins his description of Slavdom's 'latitude' not from 'his' North but from the South. 
bookish learnedness. But the measure might have been used at least partly on purpose, in order to mentally bridge, in a way, the ancient world with Slavdom, Poland being part of the latter. Thus, the procedure would have been similar to that applied by Master Vincentius a hundred years later. ${ }^{28}$ The reciprocal arrangement of the aforesaid toponyms and ethnonyms is shown by Gallus in a basically correct manner, which attests that Gallus was familiar with the geography of the Black Sea region. It was, however, a learned geography, based on paradigmatic knowledge which could, but did not have to, translate into the chronicler's actual contacts with the region - especially given the fact that, for example, the spatial concept of the chronicle's text completely ignores the Eastern Empire as a separate entity. Its parts do appear (Epirus, Thrace), but these notions are of ancient genesis and it cannot be conclusively found whether the chronicler actually thought of the ancient or his contemporary world whilst mentioning them. The north-western Dacia does not belong to this category of names: Denmark was commonly so named at the time, without any obvious connotation of the ancient Dacia.

Gallus's geographical erudition was grounded on pieces of information forming part of universal knowledge at the time, which was shared through more or less publicly accessible texts as well as through maps. Such knowledge is therefore not of use in determination of the chronicler's background, for Gallus could have acquired it in any considerable-sized monastery or cathedral library or decent school, be it in Italy, Dalmatia, the Reich, as well as Gaul. The presence of almost all the relevant texts is attested for the period for Bamberg (save for Ovid's Tristia $)^{29}$ and the terrain of what is now France. As regards Venice (and, more broadly, north of Italy) as well as Dalmatia, the issue is not as well recognised, but it seems undisputable that all the texts were available at least for the former location. Errors occurring here or there in Gallus clearly show that this author had acquired his

${ }^{28}$ Cf. Adam Krawiec, 'Wyobrażenia geograficzne w kronice Wincentego', in Andrzej Dąbrówka and Witold Wojtowicz (eds.), Onus Athlanteum. Studia nad Kronika biskupa Wincentego (Warszawa, 2009), $294 \mathrm{ff}$.

${ }^{29}$ Rudolf Blank, Weltdarstellung und Weltbild in Würzburg und Bamberg vom 8. bis zum Ende des 12. Jahrhunderts. Ein Beitrag zur Bildungsgeschichte des Mittelalters (Bamberg, 1968), 81 ff.; cf. Robert Black, 'Ovid in Medieval Italy', in James G. Clark, Frank T. Coulson, and Kathryn L. McKinley (eds.), Ovid in the Middle Ages (Cambridge, 2011), $134 \mathrm{ff}$. 
knowledge rather long before he wrote his chronicle. His description of Poland mistakes the names of winds/directions, defining Bohemia and Moravia as located a subsolano, instead of a libonoto or ab africo, from Poland ('Proemium', p. 7): subsolanus was an eastern wind/direction. According to Marian Plezia, giving a name to the sea in the north of Poland, Gallus mistook the sea goddess Amphitrite with Amphitryon, the mythical king of Tiryns. ${ }^{30}$ The most unusual identification of Sarmatians and Gethians seems to be reminiscent of the author's earlier acquaintance with Tristia: in Ovid's poem, both ethnonyms reappear one beside the other but refer to two different peoples. ${ }^{31}$ Another possible trace leads to Martianus Capella who mentions the 'Getae' and the 'Sarmatae' amongst the peoples living 'beyond' Thrace. ${ }^{32}$ Actually, Gallus might have possibly borne both texts in mind, drawing the form Sarmatici from the former and the idea to indicate this tribe as the north-eastern neighbours of Slavs or, putting it in more specific terms, the inhabitants of the area north of Thrace, from the latter.

In the chronicle's textual space concept, the territory of Europe is represented in an unequal way, with two discernible main and better described areas: the Sclavonia and the south of Gaul. However, no conclusions can be drawn on this basis as far as the author's mental geography is concerned. Gallus described in a more detailed manner only some parts of Europe not because he knew no other areas: indeed, we do not know which areas he was aware of. The criterion in his selection was the importance of areas from the standpoint of the history he meant to compile. The reasons for the relatively detailed discussion of Poland are plain. The description of central Europe the Slavdom - formed, as if, a territorial context for Poland as the arena of the history of life of Boleslaus the Wrymouth (Bolesław Krzywousty), the chronicle's protagonist. The vicinity of St Gilles was given the key role in the story of miraculous conception of Boleslaus.

${ }^{30}$ Anonim tzw. Gall, Kronika Polska, 10, n. 1. Karol Maleczyński points, for that matter, to the reference to Ovid's Metamorphoses, see Galli Anonymi Cronicae et gesta ducum sive principum Polonorum, ed. idem (Monumenta Poloniae Historica, S.N., 2, Kraków, 1952), 7, n. 7.

${ }^{31}$ Ovidius, Tristia, ed. John B. Hall (Leipzig and Stuttgart, 1995), e.g.: V, 12, 58: "nam didici Getice Sarmaticeque loqui"; V, 7, 10: "Sarmaticae maior Geticaeque frequentia gentis". Sarmatians and Gethians are mentioned in Tristia one beside the other in multiple places.

${ }^{32}$ Martianus Capella, VI, 656, p. 231. 
The reappearing thread of geographical and mental remoteness of Poland from the rest of the civilised, i.e. Christian, world seems to echo Gallus's own mental geography. This is visible already in the 'Proemium' where the chronicler justifies his description of Poland with the country's distance from pilgrimage and trading routes. The description of Poland and the further narration also emphasises the country's northern location at the edge of the oecumene; Boleslaus the Wrymouth is several times called 'the prince of the North'. Thus, in Gallus's concept, Poland was situated at the borderland of two realities: the civilisation, represented by the countries neighbouring on Poland in the east, south and west; and, the savage heathen 'antiworld' situated in the north. This procedure was plausibly aimed, at least to some extent, at featuring the role of Duke Boleslaus as a hero who expands the frontiers of Christianitas as the World (in the strict sense of the word), turning the barbarian pagans into good Christians.

The motif of Poland's isolated position with respect to St Gilles - which probably implies the rest of the Christian world - appears twice in the description of Duke Ladislaus (Władysław) Herman's deputation to the abbey: the Polish envoys are described as traversing per terras quas non noverant; and, the monks at St Gilles pray that God's name be exalted apud gentes incognitas through fulfilment of the duke's request (I, 31, p. 59). In the former case, the author might have assumed the envoys' perspective, following their account, or simply attempted to find an appropriate rhyme to the phrase "Nec mora missi properant". The context of the latter dictum, and of the aforementioned explanation of the reason behind the description of Poland seemingly indicates that what we encounter here possibly reflects the author's own mental geography as well as his feelings: in some unknown circumstances, perhaps as an exile, he once found himself in a remote, 'wild' or barren country, unknown to his native land - wherever it might have been. The fact that Gallus highlights Poland and its ruler as part of the North, as a broad concept, is not necessarily only implied by his acceptance of the local perspective of his informants: it is part of his image of Duke Boleslaus, portrayed as a suppressor of the heathens, and ascertains the simple fact that Poland is situated more northward than the chronicler's place of origin. This approach is possibly interpretable also in the context of the symbolism of the directions of the world, as prevalent in Gallus's time - with the North as the 'evil' direction. 
Gallus's geography of the aforementioned territories seems very precise - but this precision is seeming only. A series of unclear elements can be identified which arouse interpretative doubts. First, the terms used by Gallus are not always fully clear - the best known example being the problems with identification of what he refers to as Selentia and Bazoarium. The options for Selentia proposed so far include the land of the Lutici; ${ }^{33}$ the Lubusz Land, including Sulęcin, ${ }^{34}$ a faction of the Yotvingians, named 'Silia' in certain sources, ${ }^{35}$ an ephemeral small west-Pomeranian state at the estuary of the Oder River, which was smashed by Boleslaus the Wrymouth in the second decade of the twelfth century; ${ }^{36}$ or, the territory of the Veleti. ${ }^{37}$ The 'diplomatic' proposition of M. Plezia, who described Selentia as "some western Slavonic territory, west of Pomerania"38 seems to be the most appropriate conclusion, though one cannot still be certain about it. Such situation of the land or country would follow from the sequence of the names appearing in Gallus, but this author offers a disturbed order elsewhere: the countries neighbouring on Poland are mentioned in clockwise order, except for the last, western, section where Dacia/Denmark and Saxony are mentioned reversely ('Proemium', p. 7) ${ }^{39}$ The locality of Bazoarium, known to Gallus primarily because of the church whose construction was commenced by King Peter the Venetian, was identified by scholars in an extremely extensive range - as Hungary, ${ }^{40}$ Venice, ${ }^{41}$ or even as far

${ }^{33}$ E.g.: Karol Buczek, 'Ze studiów nad kroniką Galla Anonima. Sprawa Selencji', Roczniki Historyczne, xiv (1938), 1-28.

${ }^{34}$ Tyc, $Z$ dziejów kultury, 79.

${ }^{35}$ Eugeniusz Kucharski, 'Co oznacza nazwa "Selencja” w kronice Galla Anonima', Kwartalnik Historyczny, xl (1926), 145-50.

${ }^{36}$ Oskar Kossmann, 'Das unbekannte Ostseeland Selencia und die Anfänge Pommerns', Zeitschrift für Ostforschung, xx (1971), 641-85.

${ }^{37}$ M.in. Andrzej F. Grabski, 'Gall Anonim o Selencji i Prusach', Rocznik Olsztyński, ii (1959), 9-20.

${ }^{38}$ Anonim tzw. Gall, Kronika polska, 10, n. 2.

${ }^{39}$ Cf. Dariusz Sikorski, 'Galla Anonima wiadomości o Prusach. Próba weryfikacji wybranych hipotez', Kwartalnik Historyczny, cx, 2 (2003), 17.

${ }^{40}$ Plezia, Kronika, 159-60, having discussed the earlier identifications: Borsod on the Tisza and Vasvár on the Raab, this author opts for Pecs; Gerard Labuda, 'Bazoar w kronice Galla. Próba identyfikacji', Studia Historyczne, xii (1969), 161-70, conjectures it was Vác on the Danube; Tadeusz Lewicki, 'Bazoarium w Kronice Galla-Anonima', Onomastica, xiii (1968), 170-1, and Bagi, Królowie wegierscy, 135-6 (plus the Hungarian scholars referred to therein) resolutely point to Buda. 
as Jerusalem. ${ }^{42}$ It is unknown who the chronicler actually referred to while mentioning the Sarmatians-Gethians; T. Tyc would interpret these names as denoting "Lithuanian-Latvian peoples" or "nomads of eastern Europe". ${ }^{43}$ The latter option seems the most probable, taking into account that Gallus situated the 'Sarmatians' east of Ruthenia. It might however be the case that he only disguised the scarcity of specific data at this point by his overall erudition, as (for instance) B. Kürbis once suggested. ${ }^{44}$ It is not quite clear, either, whether the northern neighbours of Poland were perceived by Gallus as part of the Sclavonia, especially that Prussians were identified as derived from the Saxons. T. Tyc has formulated similar doubts with respect to Hungarians. ${ }^{45}$ It seems, however, that the answer ought to be positive: the Sclavonia in Gallus was a geographical, rather than ethnical, entity; moreover, both of the mentioned ethne were considered Slavonic, in spite of the identifiable linguistic differences and ethnogenetic traditions. It is relevant to note here that Gallus does not unambiguously differentiate between the terms Polonia and Sclavonia. Such dual understanding of the notion of Slavdom - as all the lands inhabited by Slavs, in general, and a specified country Poland, Bohemia, Polabia, south-Slavic Slavonia - was widespread in the chronicler's time. ${ }^{46}$ Yet, Gallus probably applies this procedure deliberately, in the intention to render Poland more closely associated with the rest of the civilised world, thus somewhat neutralising, as it were, the otherwise emphasised impression that the country was situated at the proverbial 'end of the world'. It is perhaps a terminological ambiguity similar to that encountered for the names of Gaul and Provence, since Gallus at first seems to treat them as referring to different countries ('Epistola', 1, p. 5) but later on makes Provence part of Gaul (I, 30, p. 57).

${ }^{41}$ Danuta Borawska, 'Gallus Anonim czy Italus Anonim?', Przegląd Historyczny, lvi (1965), 114-19.

${ }^{42}$ Mieczysław Bednarz, 'Sanctus Petrus de Bazoario w Kronice Galla Anonima', Studia Historyczne, xiv (1971), 429-30.

43 Tyc, $Z$ dziejów kultury, 85.

${ }^{44}$ Kürbis, 'Kształtowanie się pojęć', 274.

45 Tyc, $Z$ dziejów kultury, 84. This author states (overly blankly) that, according to Gallus, the southern and northern Slavdom were split by an 'occupation' of non-Slavonic Hungarians, though nothing of the sort is implied by the chronicle.

${ }^{46}$ Cf. Tyc, Z dziejów kultury, 90-1; Bagi, Królowie wegierscy, 197-9. 
A puzzling element in Gallus's geography is the gap appearing west of Poland. Saxony and Denmark are mentioned as Poland's western neighbours, the Polabian Slavdom and the March of Meissen being neglected. It can possibly be assumed that Polabia is concealed under the name of Selentia, but, on the other hand, the description of Boleslaus the Wrymouth's contests provides an image of iron poles fixed "in flumine Sale in medio terre eorum" (i.e. of the Saxons; I, 6, pp. 16-17). In fact, though, the Saale River did not go through 'the centre' of the Saxons' land but formed the southern section of Saxony's eastern border, separating Saxony from the Meissen March. This would stand for a Saxony being disproportionately expanded: apart from the actual Duchy of Saxony, as it stood in the late eleventh/ early twelfth century, it would seemingly encompass the entire area between Saxony and Poland. One possible explanation is that this testifies to Gallus's poor grasp of the area's reality - Saxony being the only name he could associate with the eastern territory of the Reich. But this might as well be a trace of the author's unspecified closer association with Saxony and his emotional attitude toward this land, leading to its exhibition in his own mental geography. ${ }^{47}$ Yet, the issue is not completely explicit. The mention of the Saale in medio terre might have had a symbolic overtone to it: controlling a conventional 'centre' - the central area of a country - would be tantamount to ruling the entire territory. ${ }^{48}$ Moreover, discernible in

${ }^{47}$ There are some traces, rather faint, that seemingly speak in favour of Gallus's association (of whatever sort) with Saxons or Saxony. Saxons are namely described as indomiti (cf. I, 6, p. 16) - a rare adjective taken over from Widukind of Corvey; there also is an anecdote, of unknown origin, about Saxon predecessors of the Prussians, quoted (cf. II, 42, p. 111-12). While the origin of this particular anecdote remains obscure, its narrative context is, in fact, rather easily explainable: the story was probably meant to clarify to the reader the problems Boleslaus the Wrymouth encountered in his attempts to conquer and Christianise the Prussians. Let us observe, however, that with the various explanations proposed so far, the scholars have tended to perceive the anecdote as a local product begotten in the mind of Gallus or in the circles associated with Polish ducal court; cf. Sikorski, 'Galla Anonima wiadomości o Prusach', 9-12, and 22. Tyc, Z dziejów kultury, 101-2, proposed a unique approach whereby "the legend came from the West".

${ }^{48}$ Cf. Zbigniew Dalewski, Wtadza, przestrzeń, ceremoniat. Miejsce $i$ uroczystość inauguracji władzy w Polsce średniowiecznej do końca XIV w. (Warszawa, 1996), 15 ff.; Jacek Banaszkiewicz, 'Jedność porządku przestrzennego, społecznego i tradycji początków ludu. (Uwagi o urządzeniu wspólnoty plemienno-państwowej u Słowian)', 
Gallus is a tendency to use names of lands relating not to specific political units (dukedoms) but to broader wholes. Such is the case with Ruthenia, which for Gallus was "a territorial block with the capital in Kiev"49, although his own narrative tells us that he was aware of its internal political divisions. A similar situation was the case with Pomerania ${ }^{50}$ and, possibly, Provence. The term 'Saxony', as used in Gallus, may possibly be understood similarly. Johannes Fried has pointed out to yet another gap appearing in the chronicle's description of Slavdom: namely, Franconia is omitted, Bamberg in particular, which in this author's opinion proves that Gallus came from this very locality. ${ }^{51}$ Whereas the appearance of this gap is a fact, the conclusions drawn thereupon by this scholar seem too far-fetched and rather misleading.

An interesting outcome is produced when superimposing the terms used by Gallus on a contemporary map, with the actual locations of the lands he mentions plotted thereon. It then becomes apparent that the areas enumerated in the chronicler's description of Slavdom form parallel zones. These zones do not, however, go exactly east to west but are twisted at some 40 degrees, beginning at the south-east, proceeding to the north-west, and finally turning straight west, or even heading somewhat south-west. This might imply that Gallus's construction of his mental map of the territory commenced with the south - the Adriatic coast. He built his idea of central Europe starting with the coasts of Adriatic Sea and Mediterranean Sea. He subsequently pondered what lands are situated north of that southern zone, and so built the consecutive zones. He knew the least of the northern zone, and found it the most difficult to define. That the description of Sclavonia opens with the north stems, therefore, from the convention assumed (Poland being described first, as the native land to the protagonist), rather than from the way the author perceives the territory being described. These facts seem to point to a southern, rather than western, perspective of Gallus's geography. The question of the perspective Gallus took to construct his image of Slavdom was

in idem, Takie sobie średniowieczne bajeczki (Kraków, 2013), 150 ff. (rpt. from Przegląd Historyczny, lxxvii, 3 [1986], 445-66).

49 Tyc, $Z$ dziejów kultury, 80.

50 Sikorski, ‘Galla Anonima wiadomości o Prusach', 16-17.

${ }^{51}$ Johannes Fried, 'Czy Gall Anonim pochodził z Bambergu?', trans. Katarzyna A. Chmielewska, Przeglad Historyczny, ci, 3 (2010), 496. 
variously perceived by researchers, who usually considered it in the context of the chronicler's provenance, using their view to support their own theories and, naturally, coming to extremely varying conclusions. ${ }^{52}$ This approach is not quite appropriate since the perspective in question indicates, at the best, the (west or south) direction from which Gallus had arrived in Poland, and not what his place of origin was. At this point, it is worthwhile, though, to assume a broader approach towards the question of reasonableness of the arguments used in the discussion on Gallus's background - insofar as they refer to this author's geographical knowledge and/or imaginations.

The accuracy of Gallus's description of the environs of the St Gilles convent, which has been pleaded by adherents of the 'French option', ${ }^{53}$ is actually ostensible; for instance, St Gilles was not part of Provence as such. The chronicler might have acquired knowledge of the place from Ladislaus Herman's envoys in Poland and from Odilo, the abbot of St Gilles, and the Crusaders, particularly of the group of Raymond of St Gilles in Hungary (directly or indirectly). ${ }^{54}$ It is worth noting that the tendency to call the inhabitants of southern Gaul, at large, 'Provençals' came as a result of the First Crusade; ${ }^{55}$

${ }^{52}$ Wojciech Kętrzyński, 'Niektóre uwagi', 59, indicates a south-Slavonic perspective in this respect; Stanisław Kętrzyński, 'Gall-Anonim i jego kronika', Rozprawy Wydziału Historyczno-Filozoficznego Akademii Umiejętności, xxxvii (1898), 50, points generally to a southern European standpoint, with an emphasis on France. Tomasz Jasiński, O pochodzeniu Galla Anonima (Kraków, 2008), 17 (and elsewhere passim), wrote about a Venetian perspective, a view that was opposed by Przemysław Wiszewski, 'Obcość Anonima zwanego Gallem', in Filip Wolański (ed.), Staropolski oglą świata - problem inności (Toruń, 2007), 18, n. 13. Also Fried, 'Czy Gall Anonim', 495-6, rejects the Venetian option, tracing instead in the Gallus description a western - specifically, Bambergian - perspective. Finally, Jarosław Wenta, Kronika tzw. Galla Anonima. Historyczne (monastyczne i genealogiczne) oraz geograficzne konteksty powstania (Torun, 2011), 90, opts, in broader terms, for a southern German perspective.

${ }^{53}$ As e.g. in Kętrzyński, 'Gall-Anonim', 51: "his knowledge is so accurate in all the details that one would not conjecture that this might have been written by anyone else than somebody well-versed in the vicinage [i.e., France]".

${ }^{54}$ Tyc, $Z$ dziejów kultury, 81-2, proposed a similarly-focused argument. For the route marched by Raymond from Provence to Constantinople, see Steven Runciman, History of the Crusades, i: The First Crusade and the Foundations of the Kingdom of Jerusalem (Cambridge, 1951; several editions afterwards), $160 \mathrm{f}$.

55 Édouard Baratier, 'Marquisat et comtés en Provence', in idem (ed.), Histoire de la Provence (Toulouse, 1969), 134-5. 
thence, the analogous stretched use of the name 'Provence', with no relation whatsoever to the local political turmoil otherwise pointed to by Jarosław Wenta. ${ }^{56}$ The presence of a description of the monastery's location in the chronicle, which M. Plezia took as an argument in support of his view, ${ }^{57}$ satisfactorily explains the importance of the hub for the building of the image of the chief protagonist.

Gallus interest in the Crusades ${ }^{58}$ explains, moreover, one of the arguments used in support of the Venetian option: the precise enumeration of the lands or provinces along the eastern coast of Adriatic Sea, the other lands within the region remaining unmentioned. As Daniel Bagi noticed, not only the Venetian trading route but also the march route of the Crusaders went through the countries enumerated by Gallus. ${ }^{59}$ The choice presented might have resulted from the chronicler's curiosity focused on the course of the crusade, or was a deliberate procedure applied in order to bridge the peripheral Poland/Slavdom to the great history of Christianitas. The sequence of the names is derived from the general rule - based on the period's geographic standards followed by Gallus - of commencing a description from the East. Moreover, as Przemysław Wiszewski has noted, not only Venice but also Aquileia is mentioned as the end point of the southern zone. ${ }^{60}$ The omission of Bulgaria, astonishing as it might seem, is probably owed to the fact that by Gallus's time the country had remained under the Byzantine rule for a hundred years, and thus this author did not conceptualise it as a separate territorial unit. Bulgaria might, for a change, possibly be part of Thrace, the area Gallus mentions; still, the south-eastern edge of Slavonic realm is rather vaguely portrayed in the chronicle's spatial concept. The analogy derived by this author between Biograd-na-Moru and Białogard (Belgard) in Pomerania ${ }^{61}$ would not point to the chronicler's Dalmatian background: his sojourn in Hungary at the time of Coloman's warfare would perfectly suffice.

56 Wenta, Kronika, 91.

57 Plezia, Kronika, 142.

${ }^{58}$ For more on Crusade-related concepts in Gallus, see, especially, Andrzej F. Grabski, 'Polska wobec idei wypraw krzyżowych na przełomie XI i XII w. "Duch krzyżowy” Anonima Galla', Zapiski Historyczne, xxvi, 4 (1961), 37-63.

${ }^{59}$ Bagi, Królowie wegierscy, 180-1.

${ }^{60}$ Wiszewski, 'Obcość', 18, n. 13.

${ }^{61}$ As indicated by Jasiński, O pochodzeniu, 86 ff. 
Contrary to what J. Wenta proposes, ${ }^{62}$ the discussion on the territorial background of Gallus cannot make use of the geography of the trading route from Germany to Ruthenia as an argument. The passage "sed quia regio Polonorum ab itineribus peregrinorum est remota, nisi transeuntibus in Rusiam pro mercimonio paucis nota" ('Proemium', p. 6) is liable to varied interpretation. It is not certain, though nowise precluded, that it refers to the chronicler's personal experience of Regensburg as the hub of trading with Ruthenia. Yet, the passage may equally well echo Gallus's experiences of Poland where he encountered the merchants as the only secular people from the West. The phrase he uses might as well be proverbial, denoting one who does business with the remote land of Ruthenia as extremely travelled and knowledgeable of the world; otherwise, it might mean 'almost nobody'. Wenta's statement that

Hungary, the Duchy of Saxony and Bavaria have determined, in a way, the place matching the Pilgrim's [i.e., Gallus's] geographical account. The precision of his geographic observations is only visible in the description of the northern frontier of Bolesław's dukedom and the southern Bavarian and Carinthian duchies, marches and counties, with Carinthia in the lead, ${ }^{63}$

is more convincing. Save for the description of the North, which is actually rather questionable, Wenta is quite right - especially once we accept the extended interpretation of the notion of 'Saxony'.

As far as the geographical arguments proposed by J. Fried with regard to Gallus are concerned, only those of his observations which take a critical stance towards the arguments of other scholars are acceptable. ${ }^{64}$ The arguments quoted in favour of his Bamberg theory are much less convincing. In the context of the aforementioned merchants issue, the finding that

Gallus assumes at this point a perspective of somebody looking at Poland from the west and not from the south, his field of vision embracing the great pilgrimage hubs of Jerusalem, Rome, and Santiago de Compostela, ${ }^{65}$

62 Wenta, Kronika, 96-7.

63 Ibidem, 90.

${ }^{64}$ As with the remark that what Gallus's reports on Liège, Gaul, and southern Slavdom lands is part of his paradigmatic knowledge, rather than being based on his personal relationship with the areas described; cf. Fried, 'Czy Gall Anonim', 494-5.

65 Ibidem, 495. 
which refers to the 'Proemium' excerpt quoted above, is only apparently apt, as no pilgrimage route was set through Poland at that time whatsoever. Gallus thus only states a simple fact, noticeable from any perspective; besides, we encounter, once more, Poland as a country situated remotely from the rest of the Christian civilisation - the motif so characteristic of this author. The reference to the Bamberg gap in the description of Sclavonia as an ex silentio argument ${ }^{66}$ deserves the name odd.

To sum up, the geographical information provided by Gallus Anonymus is practically useless in the discussion on this author's place of origin. The concept of space presented in the Cronica proves to be satisfactorily explainable with use of a combination of four factors identifiable in this work: a decent general education of this anonymous author, his interest in the Crusades, his sojourn in Hungary (unchallenged in scholarly research), and his talks whilst in Poland with the local informants. This is also true for the perspective of his description of Slavdom, as demonstrated above. Hence, in determining Gallus's geographical background, other categories of argumentation have to be employed - as is the case, for example, with the linguistic/stylistic aspects (successfully investigated by Tomasz Jasiński and other researchers).

trans. Tristan Korecki

\section{SELECTED BIBLIOGRAPHY}

Galli Anonymi Cronicae et gesta ducum sive principum Polonorum, ed. Karol Maleczyński (Monumenta Poloniae Historica, S.N., 2, Kraków, 1952).

Bagi Daniel, Królowie wegierscy w Kronice Galla Anonima (Kraków, 2008).

Borawska Danuta, 'Gallus Anonim czy Italus Anonim?', Przeglad Historyczny, lvi, 1 (1965), 111-19.

Bujak Franciszek, Studja geograficzno-historyczne (Kraków, 1925).

Fried Johannes, 'Czy Gall Anonim pochodził z Bambergu?', trans. Katarzyna A. Chmielewska, Przeglad Historyczny, ci, 3 (2010), 483-501.

Jasiński Tomasz, O pochodzeniu Galla Anonima (Kraków, 2008).

Kętrzyński Stanisław, 'Gall-Anonim i jego kronika', Rozprawy Wydziału HistorycznoFilozoficznego Akademii Umiejętności, xxxvii (1898), 40-88.

Kętrzyński Wojciech, 'Niektóre uwagi o autorze i tekście najdawniejszej kroniki polskiej', Roczniki Akademii Umiejętności. Wydziat Historyczny, liii (1909), 54-69.

${ }^{66}$ Ibidem, 496. 
Krawiec Adam, Ciekawość świata w średniowiecznej Polsce. Studium z dziejów geografii kreacyjnej (Poznań, 2010).

Kürbis Brygida, 'Kształtowanie się pojęć geograficznych o Słowiańszczyźnie w polskich kronikach przeddługoszowych', Slavia Antiqua, iv (1953), 252-81.

Plezia Marian, Kronika Galla na tle historiografii XII wieku (Kraków, 1947).

Rott Dariusz, Staropolskie chorografie. Poczatki, rozwój, przemiany gatunku (Katowice, 1995).

Tyc Teodor, Z dziejów kultury w średniowiecznej Polsce (Poznań, 1924).

Wenta Jarosław, Kronika tzw. Galla Anonima. Historyczne (monastyczne i genealogiczne) oraz geograficzne konteksty powstania (Toruń, 2011).

Adam Krawiec - medieval history; professor at the Institute of History, the Adam Mickiewicz University, Poznań; e-mail: kraam@poczta.onet.pl 